\title{
INTERLEUKIN-18 GENE POLYMORPHISM AND SOME RISK FACTORS IN IRAQI PATIENTS WITH BREAST CANCER
}

\author{
FERDOUS A JABIR ${ }^{1}$, MOHAMMED ATI AL-ASKERI ${ }^{2 *}$, WATHEQ JABER ${ }^{3}$
}

${ }^{1}$ Department of Biochemistry, College of Medicine, Al-Qadisiyah University, Iraq. ${ }^{2}$ Department of Medical Biotechnology, College of Biotechnology, Al-Qadisiyah University, Iraq. ${ }^{3}$ Department of Chemistry, College of Science, Al-Qadisiyah University, Iraq.

Email: mohammed.ati@qu.edu.iq

Received: 04 August 2016, Revised and Accepted: 29 September 2016

\section{ABSTRACT}

Objective: Breast cancer is the most diagnosed cancer in women, which leads to death in a lot of women with breast cancer. The major risk factors associated with breast cancer risk related to family history, age, clinical history, lifestyle factors, long-period hormonal exposure, and single nucleotide polymorphisms in many genes showed possible links with breast cancer incidence risk in different people populations. Our study aimed to figure out the correlation between smoking, lodging and family history, and other factors with the risk of breast cancer

Methods: Blood sample from female patients with breast cancer and healthy individuals were collected and subjected to tetra-amplification refractory mutation system-polymerase chain reaction (T-ARMS-PCR) technique for -607 C/A mutation of an interleukin (IL-18) gene and SPSS 18 software analyzed the results statically.

Results: Results showed no association between lodging and smoking with risk of breast cancer, (p>0.05), while the association between the risk and family history were obvious $(\mathrm{p}<0.05)$.

Conclusion: The results obtained by T-ARMS-PCR technique did not show the association between -607 C/An alternation of IL-18 gene and breast cancer ( $p>0.05)$ in the individuals examined in our study.

Keywords: Interleukin-18, Gene, Polymorphism, Tetra-amplification refractory mutation system-polymerase chain reaction, Mutations.

(C) 2017 The Authors. Published by Innovare Academic Sciences Pvt Ltd. This is an open access article under the CC BY license (http://creativecommons. org/licenses/by/4. 0/) DOI: http://dx.doi.org/10.22159/ajpcr.2017.v10i1.14487

\section{INTRODUCTION}

Breast cancer begins when normal cells in the portions of breast multiply and divide to compose new cells, as the body needs. When regular cells grow obsolete or damaged, it dies, and the new cells replace it [1]. Occasionally, this operation goes erroneous. New cells compose once the body does not need them, and obsolete or damaged cells don not die duly. The accumulation of additional cells often composes a mass of tissue named a lump, growth, or tumor [1,2]. It is the most frequently diagnosed cancer in women and the cause that leads to cancer death in women.

The main risk factors associated with breast cancer risk has been related to family history, age, clinical history, lifestyle factors, late first pregnancy, and long-period hormonal exposure [3].

Raised expression of a number of genes due to single nucleotide polymorphisms (SNPs) increases the breast cancer incidence risk $[4,5]$. Many researchers have demonstrated that genetic polymorphisms are one of the reasons for the individual difference in the incidence of cancer [6]

Interleukin-18 (IL), a protein of the IL-1 family, can activate immune cells without or with IL-12 [7]. IL-18 can organize both adaptive and innate immune responses during its impacts on natural killer (NK) cells, dendritic cells, monocytes, B-cells, and T-cells [8]. It can increase the immune resistance toward tumor cells by energizing and stimulating the interferon (IFN- $\gamma$ ) production and therefore has a key role in Th1 response [8].

The human has IL-18 gene is situated on chromosome 11q22.2-22.3 and composed of "6 exons and 5 introns" [9]. Three types of SNPs of the IL-18 gene in the promoter nucleotides was determined, called
$-137 \mathrm{G} / \mathrm{C}$ (rs187238), $-656 \mathrm{G} / \mathrm{T}$ or $\mathrm{rs} 1946518$, and $-607 \mathrm{C} / \mathrm{A}$ or rs1946519 [9]. IL-18 gene polymorphisms have shown correlation with different diseases such as oral cancer [10], colorectal cancer [11], thyroid cancer [12], bladder cancer [13], lung cancer [14]. and nasopharyngeal carcinoma [15]. On the other hand, other studies found there were no correlations between $-607 \mathrm{C} / \mathrm{A}$ polymorphism of IL-18 gene and head and neck squamous cell carcinoma [16] or breast cancer risk [17]. Therefore, our study aims to determine whether there is a link between -607 C/A polymorphism of IL-18 gene with the risk of breast cancer or in our Iraqi sample of the study.

\section{METHODS}

Blood samples were collected from 34 females with breast cancer who admitted AD Diwaniyha Teaching University Hospital and 21 healthy females as control group through study, groups were illustrated in Fig. 1.

IL-18 (rs1946518) polymorphisms were detected using (T-ARMS PCR), as mentioned by Taheri et al. [17]. Polymerase chain reaction (PCR) was performed using commercially available PCR premix (AccuPower PCR PreMix, BIONEER, South Korea) as described by manufacturer; $1 \mu \mathrm{l}$ template DNA (50 ng/ $\mu \mathrm{l}), 1 \mu \mathrm{l}$ of each primer $(10 \mu \mathrm{M})$, and $15 \mu \mathrm{l} \mathrm{PCR}$ water were added to each reaction. The PCR program were as follows: Initial denaturation at $95^{\circ} \mathrm{C} / 5$ minutes followed by 35 cycles; consisting of denaturation at $95^{\circ} \mathrm{C} / 30$ seconds, annealing at $54^{\circ} \mathrm{C} / 30$ seconds, and extension at $72^{\circ} \mathrm{C} / 45$ seconds with a final extension at $72^{\circ} \mathrm{C} / 5$ minutes. The PCR products were analyzed by $1.5 \%$ agarose gel electrophoresis containing $0.5 \mu \mathrm{g} / \mathrm{ml}$ ethidium bromide and visualized under ultraviolet light. Product sizes were $208 \mathrm{bp}$ for the $\mathrm{C}$ allele, $278 \mathrm{bp}$ for the A allele, and $440 \mathrm{bp}$ for control band. 
The statistical analysis between the alleles frequencies and genotype distributions of the groups were confirmed by the binary logistic regression at $\mathrm{p}<0.05$ using the SPSS 18 software. The correlation between some variables as a risk factor and breast cancer susceptibility were conducted by t-test at $\mathrm{p}<0.05$ and as a significant variation.

\section{RESULTS AND DISCUSSION}

The variables and the risk of breast cancer

The risk of breast cancer incidence with some variables such as smoking, lodging, and family history was estimated by the odd ratio and their confidence interval at $\mathrm{p}<0.05$, the matching in ages between cases and controls were demonstrated by $\mathrm{p}$ value as shown in the Table 2 .

In our study and as obvious from the results, there was not an association between lodging and smoking with risk of breast cancer occurrence ( $p$ value were higher than 0.05 ). While the association between the risk and family history were obvious $(\mathrm{p}<0.05)$, the same result obtained from a previous study [18].

Association between polymorphisms and risk of breast cancer Our study examined the correlation between 2124 and $-607 \mathrm{C} / \mathrm{A}$ (rs1946519) polymorphisms of IL-18 gene with breast cancer risk. The study was performed using tetra-amplification refractory mutation system-PCR (T-ARMS-PCR) [17]. Fig. 2 shows the PCR product of IL-18 gene on agarose gel using (100 bp DNA Ladder), the results were shown the bands of extracted DNA samples for the four groups (G1, G2, G3 and $\mathrm{G} 4)$, and the PCR product is C allele (208 bp), an allele (278 bp) and control band (440 bp).

\section{Genotype frequencies and allele distributions}

Related individuals to patients group (G2) with control group (G1)

The genotype frequencies and allelic distributions of $-607 \mathrm{C} / \mathrm{A}$ polymorphism of IL-18 in related (G2) and control (G1) groups were summarized in Table 3 . The outcomes demonstrate that the frequency of $\mathrm{CC}$ is $6.7 \%, \mathrm{AC}$ is $80 \%$, and $\mathrm{AA}$ is $13.3 \%$ in $\mathrm{G} 1$. The frequency of CA -607 polymorphism in G2 were $16.6 \%$ for $\mathrm{CC}, 83.3 \%$ for $\mathrm{AC}$, and $0 \%$ for AA. There were no significantly difference in $-607 \mathrm{C} / \mathrm{A}$ polymorphism of IL-18 between G2 and G1 ( $\mathrm{p}=0.488$ ). As shown in Table 3 in G1, an allele frequency was $53.3 \%$ and the $\mathrm{C}$ allele frequency were $46.7 \%$, and in the $\mathrm{G} 2$ the frequencies were $58.33 \%$ for $\mathrm{C}$ allele and $41.66 \%$ for An allele. The frequency of allele was not different between G1 and G2 $(\mathrm{p}=0.496)$.
Treated (G3) with control (G1) groups

The genotype frequencies with allele distributions of $-607 \mathrm{C} /$ A alternation of IL-18 in treated (G3) and control (G1) groups explained in Table 4. The results show that the frequency of CC is $6.7 \%, \mathrm{AC}$ is $80 \%$, and $\mathrm{AA}$ is $13.3 \%$ in G1. The frequency of CA -607 alternation in G3 were $23.8 \%$ for $\mathrm{CC}, 71.4 \%$ for $\mathrm{AC}$, and $4.8 \%$ for $\mathrm{AA}$. There were not significantly difference in -607 C/A polymorphism of IL-18 between G3 and G1.As shown in Table 3 in G1, an allele frequency were 53.3\% and the C allele frequency were $46.7 \%$, and in the G3 the frequencies were $59.5 \%$ for an allele and $41.66 \%$ for C allele. Logistic regression analyses indicated that the

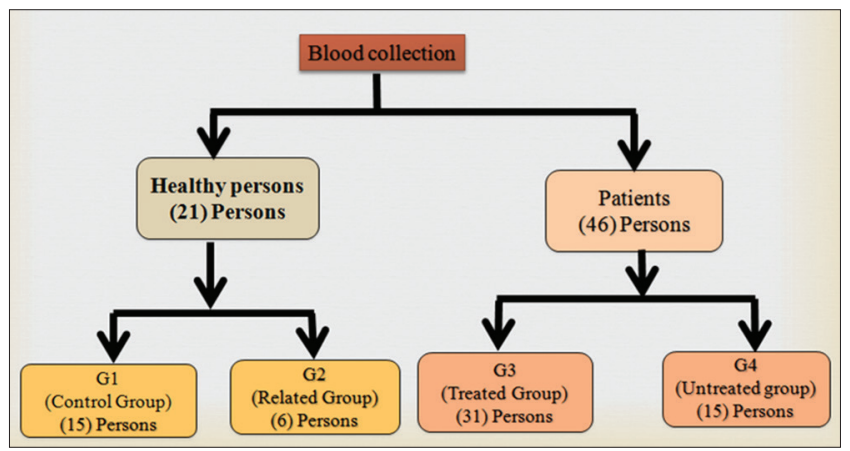

Fig. 1: Study groups and subgroups

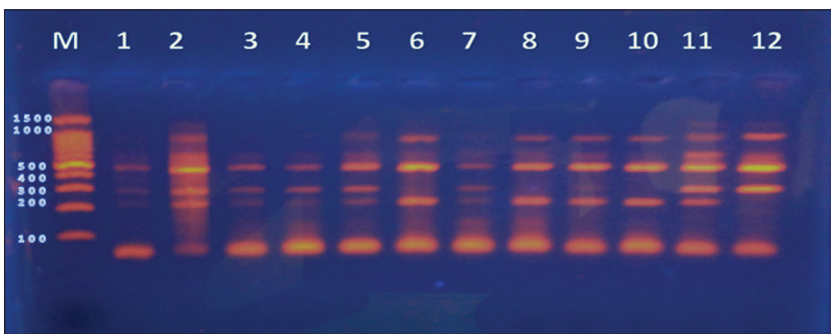

Fig. 2: Electrophoresis pattern of tetra-amplification refractory mutation system-polymerase chain reaction products for polymorphisms for interleukin-18 gene -607 C/A (rs1946519). M: 100bp DNA Ladder, Lane 1: to G4 (Untreated group), Lane 2-9: G3 (Treated), Lane 10: G2 (Related-sister of the patient No. 9) and Lane 11, 12: G1 (Control)

Table 1: IL-18 -607 C/A (rs1946518) T-ARMS-PCR primers

\begin{tabular}{ll}
\hline Primers & Sequence $\mathbf{5}^{\prime} \rightarrow \mathbf{3} \mathbf{\prime}^{\prime}$ \\
\hline Forward outer primer & CCTACAATGTTACAACACTTAAAAT \\
Reverse outer primer & ATAAGCCCTAAATATATGTATCCTTA \\
Forward inner primer & GATACCATCATTAGAATTTTGT \\
Reverse inner primer & GCAGAAAGTGTAAAAATTATCAA \\
\hline
\end{tabular}

T-ARMS-PCR: Tetra-amplification refractory mutation system-polymerase chain reaction, IL-18: Interleukin-18

Table 2: Clinical characteristic and breast cancer risk

\begin{tabular}{|c|c|c|c|c|}
\hline Variables & $\begin{array}{l}\text { Cases (G3+G4) } \\
\mathrm{N}=46(\%)\end{array}$ & $\begin{array}{l}\text { Control (G1) } \\
\mathrm{N}=15(\%)\end{array}$ & OR (95\% CI) & $p$ value \\
\hline \multicolumn{5}{|l|}{ Lodging } \\
\hline Urban & $28(60.9)$ & $8(53.33)$ & $0.563(0.174-1.821)$ & 0.334 \\
\hline Rural & $18(39.1)$ & 7 (46.77) & & \\
\hline \multicolumn{5}{|l|}{ Smoking } \\
\hline Non smoker & 43 (93.5) & $15(100)$ & 1.070 (0.991-1.155) & 0.31 \\
\hline Smoker & $3(6.5)$ & $0(0)$ & & \\
\hline \multicolumn{5}{|l|}{ Family history } \\
\hline Without family history & 34 (71.9) & $15(100)$ & $1.353(1.140-1.606)$ & $0.027^{*}$ \\
\hline With family history & $12(26.1)$ & $0(0)$ & & \\
\hline Age $($ mean $\pm S E)$ & $46.73 \pm 3.54$ & $47.93 \pm 3.05$ & & 0.988 \\
\hline
\end{tabular}

*The value is statically significant, G3 treated, G4 untreated, G1 control. SE: Standard error, OR: Odd ratio, CI: Confidence interval 
-607 C/AAC and CC genotypes did not correlate with breast cancer risk in comparison with the AA genotype $(p=0.476$ and $p=0.161)$. Alike results noticed when comparing the $\mathrm{C}$ allele with the reference $\mathrm{A}$ allele $(\mathrm{p}=0.233)$.

\section{Untreated (G4) with control (G1) groups}

The genotype frequencies and allele distributions of $-607 \mathrm{C} / \mathrm{A}$ polymorphism of IL-18 in untreated (G4) and control (G1) groups were shown in Table 5. The results show that the frequency of CC is $6.7 \%, \mathrm{AC}$ is $80 \%$, and $\mathrm{AA}$ is $13.3 \%$ in G1. The frequency of CA -607 polymorphism in $\mathrm{G} 4$ were $72.7 \%$ for $\mathrm{AC}$, $9.1 \%$ for $\mathrm{AA}$, and $18.2 \%$ for CC. There was no significantly difference in $-607 \mathrm{C} / \mathrm{A}$ polymorphism of IL-18 between G4 and G1 ( $p>0.05$ ). As shown in Table 4 in G1, An allele frequency was $53.3 \%$ and the C allele frequency were $46.7 \%$, and in the G4 the frequencies were $40.9 \%$ for An allele and $59.1 \%$ for $\mathrm{C}$ allele. Logistic regression analyses confirmed that the "-607 C/AAC and CC genotypes have not associated with breast cancer risk compared with the AA genotype $(p=0.826$ and $p=0.711)$. Alike results were noticed as comparing the $\mathrm{C}$ allele with the reference A allele $(\mathrm{p}=0.574)$."

Untreated (G4) with treated (G3)

The genotype frequencies and allele distributions of $-607 \mathrm{C} / \mathrm{A}$ alternation of IL-18 in untreated (G4) and control (G1) groups were shown in Table 6.
The results show that the frequencies were $23.8 \%$ for CC, $71.4 \%$ for $\mathrm{AC}$, and $4.8 \%$ for $\mathrm{AA}$ in G3. The frequency of CA -607 polymorphism in G4 were $18.2 \%$ for CC, $72.7 \%$ for AC, and $9.1 \%$ for AA. There was no significantly difference in -607 C/A polymorphism of IL-18 between G4 and G3 (p>0.05). As shown in Table 5 in G3, an allele frequency was 59.5\% and the $\mathrm{C}$ allele frequency were $40.5 \%$, and in the $\mathrm{G} 4$ the frequencies were $40.9 \%$ for An allele and $59.1 \%$ for C allele. Logistic regression analyses indicated so as to the -607C/AAC and "CC" genotypes were compared with the AA genotype there was an insignificant difference $(\mathrm{p}=0.467$ and $\mathrm{p}=0.368$ ). In a similar way, the results were registered when comparing the "C allele with the reference A allele ( $\mathrm{p}=0.621)$.

\section{DISCUSSION}

The family background of breast cancer occurrence is one of the most significant risk factors for the progression of breast cancer [19]. Aside from age, women with one influenced the first-degree relative are approximately twice as likely to promote breast cancer compared with women who have no influenced relatives, and risks are higher when more than one firstdegree relative is influenced or the relative is youthful at diagnosis $[19,20]$.

In our study and as obvious from the results, there is an association between family background and the risk of breast

Table 3: The genotypes and allelic distribution of IL-18 gene-607 C/A (rs1946519) in G2 and G1 groups

\begin{tabular}{|c|c|c|c|c|c|c|}
\hline Polymorphisms IL-18 (-607C/A) & $\begin{array}{l}\text { G1 (Control) } \\
\mathrm{N}=15(\%)\end{array}$ & $\begin{array}{l}\text { G2 (Related) } \\
\text { N=6 }(\%)\end{array}$ & $\chi^{2 \mathrm{a}}$ & $\mathbf{p}^{\mathbf{a}}$ & OR $(95 \% \mathrm{CI})^{\mathrm{b}}$ & $\mathbf{p}^{\mathbf{b}}$ \\
\hline $\mathrm{AA}$ & $2(13.3)$ & & 1.433 & 0.488 & $1.0^{\text {ref }}\left(1.0^{\text {ref }}\right)$ & \\
\hline $\mathrm{AC}$ & $12(80.0)$ & $5(83.3)$ & & & $0.000(0.000)$ & \\
\hline $\mathrm{CC}$ & $1(6.7)$ & $1(16.7)$ & & & $0.000(0.000)$ & 0.488 \\
\hline A allele & $16(53.3)$ & $5(41.66)$ & 0.468 & 0.494 & $1.0^{\text {ref }}\left(1.0^{\text {ref }}\right)$ & \\
\hline $\mathrm{C}$ allele & $14(46.7)$ & 7 (58.33) & & & $1.600(0.413-6.193)$ & 0.496 \\
\hline
\end{tabular}

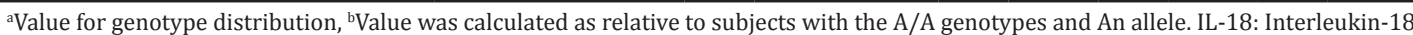

Table 4: The genotypes and allele distribution of IL-18 polymorphism in G3 and G1

\begin{tabular}{|c|c|c|c|c|c|c|}
\hline Polymorphisms IL-18 (-607 C/A) & $\begin{array}{l}\text { G1 (Control) } \\
\mathrm{N}=15(\%)\end{array}$ & $\begin{array}{l}\text { G3 (Treated) } \\
\text { N=21 (\%) }\end{array}$ & $\chi^{2 \mathrm{a}}$ & $\mathbf{p}^{\mathrm{a}}$ & OR $(95 \% \mathrm{CI})^{\mathrm{b}}$ & $\mathbf{p}^{\mathbf{b}}$ \\
\hline AA & $2(13.3)$ & $1(4.8)$ & 2.58 & 0.275 & $1.0^{\text {ref }}\left(1.0^{\text {ref }}\right)$ & \\
\hline $\mathrm{AC}$ & $12(80.0)$ & $15(71.4)$ & & & $0.400(0.320-4.960)$ & 0.476 \\
\hline CC & $1(6.7)$ & $5(23.8)$ & & & $0.100(0.004-2.504)$ & 0.161 \\
\hline A allele & $16(53.3)$ & $25(59.5)$ & 1.434 & 0.231 & $1.0^{\mathrm{ref}}\left(1.0^{\mathrm{ref}}\right)$ & \\
\hline C allele & $14(46.7)$ & $17(40.5)$ & & & $1.786(0.689-4.631)$ & 0.233 \\
\hline
\end{tabular}

${ }^{a}$ Values for genotype distribution, ${ }^{b}$ Value was calculated as relative to subjects with the A/A genotypes and An allele. IL-18: Interleukin-18

Table 5: The genotypes and allele distribution of IL-18 polymorphism in G4 and G1

\begin{tabular}{|c|c|c|c|c|c|c|}
\hline Polymorphisms IL-18 (-607 C/A) & $\begin{array}{l}\text { G1 (Control) } \\
\mathrm{N}=15(\%)\end{array}$ & $\begin{array}{l}\text { G4 (Untreated) } \\
\mathrm{N}=10(\%)\end{array}$ & $\chi^{2 \mathrm{a}}$ & $\mathbf{p}^{\mathbf{a}}$ & OR $(95 \% \mathrm{CI})^{\mathrm{b}}$ & $\mathbf{p}^{\mathbf{b}}$ \\
\hline AA & $2(13.3)$ & $1(9.1)$ & 0.138 & 0.933 & $1.0^{\text {ref }}\left(1.0^{\text {ref }}\right)$ & \\
\hline $\mathrm{AC}$ & $12(80.0)$ & $7(72.2)$ & & & $0.750(0.580-9.719)$ & 0.826 \\
\hline CC & $1(6.7)$ & $2(18.2)$ & & & $0.500(0.013-19.562)$ & 0.711 \\
\hline A allele & $16(53.3)$ & $9(40.9)$ & 0.316 & 0.574 & $1.0^{\text {ref }}\left(1.0^{\text {ref }}\right)$ & \\
\hline $\mathrm{C}$ allele & $14(46.7)$ & $13(59.1)$ & & & $1.371(0.455-4.136)$ & 0.574 \\
\hline
\end{tabular}

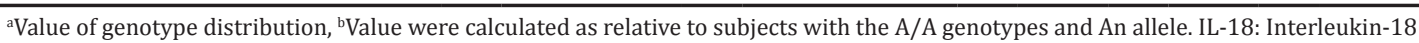

Table 6: The genotypes and allele distribution of IL-18 polymorphism in G4 and G3

\begin{tabular}{|c|c|c|c|c|c|c|}
\hline Polymorphisms IL-18 (-607 C/A) & $\begin{array}{l}\text { G3 (Treated) } \\
\mathrm{N}=21(\%)\end{array}$ & $\begin{array}{l}\text { G4 (Untreated) } \\
\mathrm{N}=10(\%)\end{array}$ & $\chi^{2 \mathrm{a}}$ & $\mathbf{p}^{\mathrm{a}}$ & OR $(95 \% \mathrm{CI})^{\mathrm{b}}$ & $\mathbf{p}^{\mathbf{b}}$ \\
\hline AA & $1(4.8)$ & $1(9.1)$ & 1.088 & 0.581 & $1.0^{\text {ref }}\left(1.0^{\text {ref }}\right)$ & \\
\hline $\mathrm{AC}$ & $15(71.4)$ & $7(72.2)$ & & & $0.533(0.029-9.708)$ & 0.476 \\
\hline $\mathrm{CC}$ & $5(23.8)$ & $2(18.2)$ & & & $0.200(0.006-6.664)$ & 0.368 \\
\hline A allele & $25(59.5)$ & $9(40.9)$ & 0.243 & 0.622 & $1.0^{\mathrm{ref}}\left(1.0^{\mathrm{ref}}\right)$ & \\
\hline $\mathrm{C}$ allele & $17(40.5)$ & $13(59.1)$ & & & $0.768(0.269-2.190)$ & 0.621 \\
\hline
\end{tabular}

${ }^{a}$ Values about genotype distribution, ${ }^{\mathrm{b} C a l c u l a t e d}$ as relative to subjects with the A/A genotypes and An allele. IL-18: Interleukin-18 
cancer occurrence, the same result obtained from a previous study [18].

Our current study aims to identify the effect of IL-18 -607 C/A mutation on the predisposition of breast cancer in our population. We found no correlation between IL-18 -607 C/A polymorphism and predisposition to breast cancer. This result similar to a previous study [17].

IL-18 can be organized both adaptive and innate immune responses during its impacts on NK cells, dendritic cells, monocytes, B-cells, and $\mathrm{T}$-cells [8]. It can raise the immune protection against cancer cells by energizing and stimulating the IFN- $\gamma$ creation and therefore has a key role in Th1 response [8]. It has been made known that IL-18 has a major role in the progression of the tumor. IL-18 expression and serum level have been shown to elevate in different cancers in the blood stream of metastatic patients compared to healthy controls and patients with no metastasis [21]. Because of the double roles of IL-18 expression and serum level in both tumor metastasis and drug resistance, IL-18 may denote a helpful drug target for therapy of breast cancer [22]. It was clear that two SNPs in the promoter area of the IL-18 gene organized the gene expression levels at the transcriptional stage and changed the IL-18 production level [17]. The alteration from the " $\mathrm{C}$ allele to the "A" allele at site $-607 \mathrm{C} / \mathrm{A}$ and at site $-137 \mathrm{G} / \mathrm{C}$ alternation from the $\mathrm{G}$ allele to the $\mathrm{C}$ allele in the (promoter area) were prophesied to be the molecular factor linking sites for the cyclic adenosine monophosphate responsive element between protein and H4TF-1 factor, respectively in addition, polymorphisms of the two positions have been correlated with the activity of IL-18 gene promoter transcription, which can impact the IL-18 expression and, may be, of IFN- $\gamma$; these changes in alleles, potentially be the essential mechanism of IL-18 involvement in different diseases [23,24]. IL-18 polymorphism has been shown correlated with different diseases such as oral cancer [10], colorectal cancer [11], thyroid cancer [12], bladder cancer [13], lung cancer [14], and nasopharyngeal carcinoma" [15].

\section{CONCLUSION}

Our study showed no significant correlation between -607 C/A polymorphism of IL-18 gene and breast cancer risk in the Iraqi individuals subjected to this study.

\section{REFERENCES}

1. Khuwaja GA, Abu-Rezq AN. Bimodal breast cancer classification system. Pattern Anal Appl 2004;7:235-42.

2. Al-Hashimi MM, Wang XJ. Breast cancer in Iraq, incidence trends from 2000-2009. Asian Pac J Cancer Prev 2014;15(1):281-6.

3. Garcia M, Jemal A, Ward EM. Global Cancer Facts \& Figures. Atlanta, GA: American Cancer Society; 2007.

4. Mahdi KM, Nassiri MR, Nasiri K. Hereditary genes and SNPs associated with breast cancer. Asian Pac J Cancer Prev 2013;14(6):3403-9.

5. Cybulski C, Wokolorczyk D, Jakubowska A, Huzarski T, Byrski T, Gronwald J, et al. Risk of breast cancer in women with a CHEK2 mutation with and without a family history of breast cancer. J Clin Oncol 2011;29(28):3747-52

6. Pooley KA, Healey CS, Smith PL, Pharoah PD, Thompson D, Tee L, et al. Association of the progesterone receptor gene with breast cancer risk: A single-nucleotide polymorphism tagging approach. Cancer Epidemiol Biomarkers Prev 2006;15(4):675-82.

7. Srivastava S, Salim N, Robertson MJ. Interleukin-18: Biology and role in the immunotherapy of cancer. Curr Med Chem 2010;17(29):3353-7.

8. Günel N, Coskun U, Sancak B, Günel U, Hasdemir O, Bozkurt S. Clinical importance of serum interleukin-18 and nitric oxide activities in breast carcinoma patients. Cancer 2002;95(3):663-7.

9. Kruse S, Kuehr J, Moseler M, Kopp MV, Kurz T, Deichmann KA, et al. Polymorphisms in the IL 18 gene are associated with specific sensitization to common allergens and allergic rhinitis. J Allergy Clin Immunol 2003;111(1):117-22.

10. Tsai HT, Hsin CH, Hsieh YH, Tang CH, Yang SF, Lin CW, et al. Impact of interleukin-18 polymorphisms $-607 \mathrm{~A} / \mathrm{C}$ and $-137 \mathrm{G} / \mathrm{C}$ on oral cancer occurrence and clinical progression. PLoS One 2013;8(12):e83572.

11. Nikiteas N, Yannopoulos A, Chatzitheofylaktou A, Tsigris C. Heterozygosity for interleukin-18 $-607 \mathrm{~A} / \mathrm{C}$ polymorphism is associated with risk for colorectal cancer. Anticancer Res 2007;27(6B):3849-53.

12. Cunha LL, Tincani AJ, Assumpção LV, Soares FA, Vassallo J, Ward LS. Interleukin-10 but not interleukin-18 may be associated with the immune response against well-differentiated thyroid cancer. Clinics (Sao Paulo) 2011;66(7):1203-8.

13. Jaiswal PK, Singh V, Srivastava P, Mittal RD. Association of IL-12, IL18 variants and serum IL-18 with bladder cancer susceptibility in North Indian population. Gene 2013;519(1):128-34

14. Farjadfar A, Mojtahedi Z, Ghayumi MA, Erfani N, Haghshenas MR, Ghaderi A. Interleukin-18 promoter polymorphism is associated with lung cancer: A case-control study. Acta Oncol 2009;48(7):971-6.

15. Pratesi C, Bortolin MT, Bidoli E, Tedeschi R, Vaccher E, Dolcetti R, et al. Interleukin-10 and interleukin-18 promoter polymorphisms in an Italian cohort of patients with undifferentiated carcinoma of nasopharyngeal type. Cancer Immunol Immunother 2006;55(1):23-30.

16. Asefi V, Mojtahedi Z, Khademi B, Naeimi S, Ghaderi A. Head and neck squamous cell carcinoma is not associated with interleukin-18 promoter gene polymorphisms: A case-control study. J Laryngol Otol 2009;123(4):444-8.

17. Taheri M, Hashemi M, Eskandari-Nasab E, Fazaeli A, Arababi F, Bahrani-Zeidabadi M, et al. Association of $-607 \mathrm{C} / \mathrm{A}$ polymorphism of IL-18 gene (rs1946518) with breast cancer risk in Zahedan, Southeast Iran. Prague Med Rep 2012;113(3):217-22.

18. Walker MJ. Breast Cancer Screening Behaviors and Outcomes in Women with a Family History of Breast and/or Ovarian Cancer in Ontario. Toronto, ON: Dalla Lana School of Public Health, University of Toronto; 2014.

19. Pharoah PD, Day NE, Duffy S, Easton DF, Ponder BA. Family history and the risk of breast cancer: A systematic review and meta-analysis. Int J Cancer 1997;71(5):800-9.

20. Bevier M, Sundquist K, Hemminki K. Risk of breast cancer in families of multiple affected women and men. Breast Cancer Res Treat 2012;132(2):723-8.

21. Park S, Cheon S, Cho D. The dual effects of interleukin-18 in tumor progression. Cell Mol Immunol 2007;4(5):329-35.

22. Yao L, Zhang Y, Chen K, Hu X, Xu LX. Discovery of IL-18 as a novel secreted protein contributing to doxorubicin resistance by comparative secretome analysis of MCF-7 and MCF-7/Dox. PLoS One 2011;6(9):e24684.

23. Giedraitis V, He B, Huang WX, Hillert J. Cloning and mutation analysis of the human IL-18 promoter: A possible role of polymorphisms in expression regulation. J Neuroimmunol 2001;112(1-2):146-52.

24. Arimitsu J, Hirano T, Higa S, Kawai M, Naka T, Ogata A, et al. IL-18 gene polymorphisms affect IL-18 production capability by monocytes. Biochem Biophys Res Commun 2006;342(4):1413-6. 